\title{
Albanian Cultural Heritage in Digital Area
}

\author{
Dr. Etleva Domi
}

National Library of Albania, Albania

Copyright $\odot 2018$ by authors, all rights reserved. Authors agree that this article remains permanently open access under the terms of the Creative Commons Attribution License 4.0 International License

\begin{abstract}
Living in the new era of "Bridging the Digital Divide: making the world's cultural and scientific heritage accessible to all", the article aims to present the mission of Albanian librarian community as a "builder" of "virtual cultural bridges" between the past and present, - by focusing mainly to the National Library of Albania. Such article provides a shortly background information on the technological revolution development in Albania and increased clients/users attention to digital information and/or digital content in the rich cultural environment where we are leaving. The author pays attention to Albanian National Library Strategy as the keeper of National Memory, its role in the knowledge age of Internet, its initiatives/projects in the national or international level, its achievements in building the Albanological Digital Library (e-Albanica), as well as its impact on the broader librarian community. Focusing on Albanian librarians' efforts to make available on-line at anytime and anywhere the cultural resources for all users,- even for the generations to come,- the study provides the promotion of Albanian richness cultural heritage in the world portals of present time, as well as the preserving of the cultural and scientific treasure. As a conclusion, the "Albanian Cultural Heritage by a click of mouse" is a "new channel" in the universe of knowledge breaking the concept of "physical boundaries", "building bridges" and "connecting cultures across the world".
\end{abstract}

Keywords Digital Libraries, Albanian Heritage, Access to Information, Digitization

\section{Introduction}

Nowadays, the digitization of cultural and scientific heritage has become a world-wide phenomenon and the interest of librarians and information professionals community is increasing, as well as considering that in all over the world several initiatives are undertaken and a lot of conferences are organized in relation to application of information technologies in the field of digitization, the topic of development of "Albanian Digital Library" comes with a background information about technological developments.

\section{Technological Revolution and Information Sector in the New Millennium}

In the early 1990s, the wave of democratic changes in South-Eastern European Countries affected even the Albanian coast. Nowadays, citizens feel free to easily navigate, search and find through different ways everything that they need in a new information era without barriers and restrictions by facilitating more and more the "MAGICAL technological revolution" such as: computers, laptops, mobile phones, smart phones, iPods, I Phones, tablets, e-Kindles, Internet, - tools that change their everyday life.

Currently, at the time when "There is nothing permanent except change" [1], the Albanian librarian community is living in an era where the explosion of technological revolution has broken the "physical boundaries' between "countries" and traditional concepts such as: Space-Time-Distance and "library walls". At the time when Internet is transforming the entire information society, the concept of change into perspective consists of looking at the "Five Laws of Librarianship", especially to the fifth one as it is proposed by one of the greatest librarians of all times, S.R. Ranganathan of India "The Library is a Growing Organism" [2]. In today's high-tech era, the digital information is bombarding all over the world including even the Memory Institution. Nowadays, a huge mass of cultural or scientific information is becoming more and more available through a lot of portals that allow users to have infinitely options to choose and navigate in the virtual cyberspace.

In this context, "Bridging the Digital Divide: making the world's cultural and scientific heritage accessible to all" [3], is one of the most important mission of librarian community, - as a "builder" of "virtual cultural bridges" between the past and present. Over the last 20 years, dramatic changes in Albanian society have occurred by positively influencing even the library community where 
the libraries remain as mediators of the accumulated cultural heritage.

"Digital books offer new opportunities for access to knowledge, at reduced costs and over wide geographical areas. Traditional books are still powerful technology: failsafe, portable and standing the test of time. All forms of books make a valuable contribution to education and the dissemination of culture and information. The diversity of books and editorial content is a source of enrichment that we must support through appropriate public policies and protect from uniformity. This bibliodiversity is our common wealth, making books much more than a physical object, for they are our most beautiful invention for sharing ideas beyond the boundaries of space and time" [4].

Since a lot of digitization initiatives are under way over the entire world and taking into account the European Council Recommendation: "A common access point for Europe's digital cultural heritage", the digital initiatives could not be missed in Albania. In the end of XX century, at the time when "digital flowers" started to flourish day after day in "Albanian garden", "garden librarians" became more conscientious for their increasing role in "Digital Revolution" by visualizing the future of users with the conviction that libraries in future will depend on what librarians have done today.

In the society of cultural diversity, paying attention to the local and/or national cultural heritage was/is/will be a priority objective for numerous cultural institutions or libraries involved in digital activities even in the future. However, the study is mainly focusing on National Library of Albania (NLA) as the National Memory keeper of cultural heritage, as well as a leader in preserving and promoting cultural heritage and cultural memories of the nation in world portals.

\section{The National Library of Albania Strategy}

\subsection{Automation Project-background}

While the national information infrastructure did not exist, the NLA, that is, the main library institution that welcomed the first PCs in 1990, began the first steps towards electronic catalog in 1994 thanks to CDS/ISIS, constructed a local network (LAN) in 1998, installed an integrated library software (Adlib) in 1999 and made searchable library database through OPAC in $2000-$ consists of one of the pioneer's institutions that had implemented the news technologies in our country. In the end of December 2016, the automated catalog of NLA contained 395,761 records.

Table 1. The National Library of Albania Database

\begin{tabular}{|c|c|c|c|c|}
\hline Year & 2013 & 2014 & 2015 & 2016 \\
\hline Database & 325,207 & 352,392 & 378,590 & 395,761 \\
\hline
\end{tabular}

As the responsible institution for providing access to the national heritage, the NLA staff has been distinguished for its serious efforts to be ready for Europe Vision 2020 by building digital "bridges" and bringing the past and present digital content in the hand of everyone, at anytime and anywhere for all citizens.

Bearing in mind the IFLA/UNESCO Manifesto Recommendation providing "Equal access to cultural and scientific heritage of mankind is every person's right and help promote learning and understanding of the richness and diversity of the world, not only for the present generation, but also for the generations to come" [5], the National Library of Albania started to compile pilot projects and find intelligent and economic solutions in order to make the "digital dream" a "reality". In the present decade, ICT's impact is evident. New library trends are powerfully growing and the access at any time and from everywhere to usable information/knowledge/treasure "rooms" is "without door". Therefore, the digitalization of National Heritage is not a myth, but it represents a reality.

\subsection{Digital Library Centre}

Taking into account that the new millennium future is considered to be digital in accordance with the European Council Recommendations, the National Library of Albania policy vigorously advocates the necessity of a Digital Library Center. The constitution of such kind of center builds more digital collections, offers more and more possibilities and/or accesses to digital cultural and scientific contents with a "mouse click" to all treasures of humanity.

The new founded laboratory was inaugurated in 2013 and is equipped with the latest news technological tools. Such laboratory provides not only a rapid mass digitalization of national heritage, but it also provides high quality access to digital library collections and services to global online community.

\subsection{Projects}

\subsubsection{National Level}

\subsubsection{Digital Conversion of Card Catalogue of Special Collections}

The first initiative of information digitalization dated on 2007. With the aim of making accessible the national heritage information for global user community, the NLA have undertaken the project of Digitization of Information: Digital Conversion of Card Catalogue of Special Collections. The Digitized Card Catalogues, including digital images of printed/manual catalogue cards of manuscripts and antiquaries, are actually available online. In fact, such content is very useful for the global scholars and researchers during their activity. 

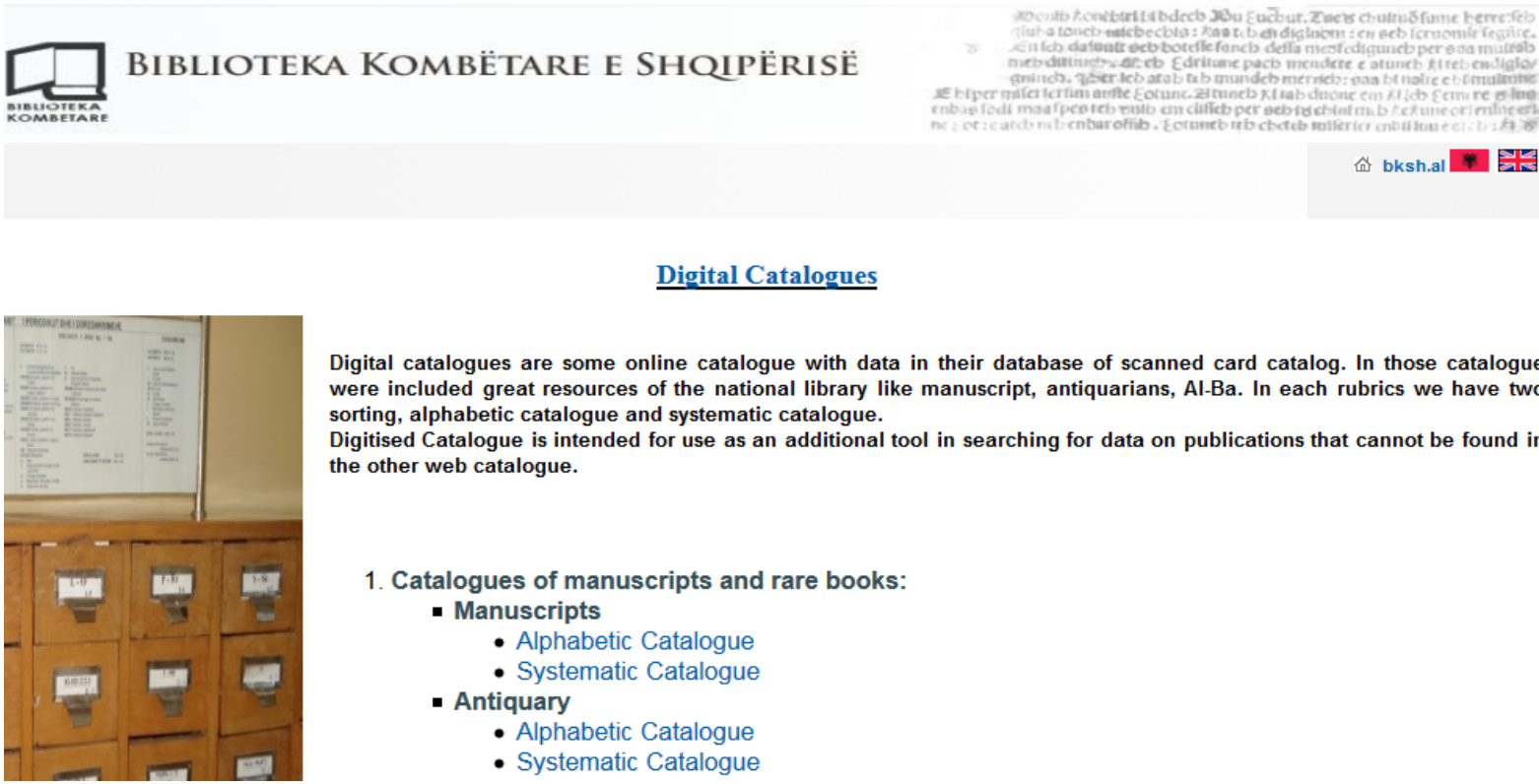

Digital catalogues are some online catalogue with data in their database of scanned card catalog. In those catalogue were included great resources of the national library like manuscript, antiquarians, Al-Ba. In each rubrics we have two sorting, alphabetic catalogue and systematic catalogue.

Digitised Catalogue is intended for use as an additional tool in searching for data on publications that cannot be found in the other web catalogue.

1. Catalogues of manuscripts and rare books:

- Manuscripts

- Alphabetic Catalogue

- Systematic Catalogue

- Antiquary

- Alphabetic Catalogue

- Systematic Catalogue

Available online: http://www.bksh.al/BibliotekaKombetare/Home.aspx

Figure 1. Digital Card Catalogue

\section{$\prod_{\substack{\text { natheres } \\ \text { KOMmethat }}}$ BIBLIOTEKA KOMBËTARE E SHQIPËRISË}

e-ALBANICA

e-Albanica përfaqëson Bibliotekën Digjitale Albanologjike. Përmban vepra të rralla të Bibliotekës Kombëtare, dorëshkrime, harta dhe periodikë të shekujve XV-XIX në gjuhën shqipe dhe në gjuhë të tjera.

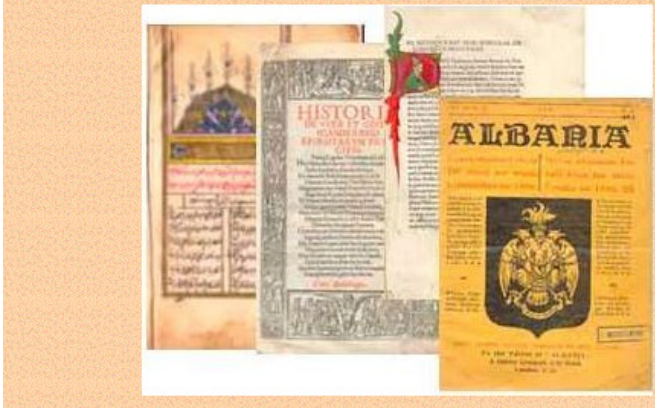

\begin{tabular}{c} 
LIBRA \\
\hline ANTIKUARË \\
\hline DORËSHKRIME \\
\hline PERIODIKË \\
\hline HARTA \\
\hline
\end{tabular}

Available online: http://www.bksh.al/gsdl/cgi-bin/library.exe

\section{Figure 2. E-ALBANICA}

\subsubsection{Digital Library}

Digital Library Strategy is one the most important priorities of the National Library of Albania

The NLA is the holder of national cultural and scientific heritage. In such context, the archive collections, antiquaries, manuscripts, maps and Albano-Balcanological collections constitute assets of great value among the NLA's library materials.

As a Memory Institution that preserves the memory of mankind, the above-mentioned special collections represent "diamond" stones in the whole universe. The Albanian librarians, - as members of global librarian community and "bridge builders" of virtual "world castle memory", - are conscious for their responsible mission as cultural heritage keepers in the new digital era, which is important for the present and future.

In 2009, the National Library of Albania started to develop its own Digital Library Strategy. The first 
Albanian Albanological Digital Library was baptized e-ALBANICA, which succeeded in making available its collections to a wider readership by creating a gateway to national heritage resources from XV-XIX centuries in Albanian and/or foreign languages concerning the history and culture of Albania. In this point of view, the further development of digital library strategy is an imperative necessity for NLA.

In the end of September 2017, 5300 "digital objects" are counted in this small "Albanian digital village". Such "digital objects" include: antiquarian books, manuscripts, rare maps collection, Albanian periodicals, books (without copyright), bibliographies and generally satisfy the needs and requirements of clients/users. In the meantime, around 900 "digital objects" are currently online, while the others can be accessible indoor. Furthermore, the Department of Information and New Technologies is working to make available online all the digital collections and to periodically increase the new units.

The antiquary collection consists of a rare and precious publication of XV-XVIII centuries, bookbinding's, decorated books and incunabula. The earliest publication containing data on Albania dates on 1473. In such a special collection, the following works and publications are preserved: works published in Albanian language; original works of Albanian authors (Budi, Bardhi, Bogdani, Matrenga etc.) and other Albanian humanists of 16-th century (Barletius, Beccichemus etc.); publications printed in Voskopoja Printing House during the XVII century that indicate the development of country's printing press; works of well-known Greek and Latin authors (Herodotus, Aristotle, Strabon, Ptolemaeus, Apianus etc.) that provide data on Illyrians; works of Byzantine historians and/or chroniclers (Anna Commena, Chalcocondylas etc.) that provide data on the medieval history of Albania; works in Italian, French, German, English language of European humanists (Lavardin, Duponcet, Sarrocchi, Du Verdier, Biemmi, etc.)

In a total of 247 digitized antiquary books, a part of them is already available online: http://www.bksh.al/gsdl/cgi-bin/library.exe?e=p-00000-00 ---off-0--00---0-10-0---0---0prompt-10---4-------0-11--10-e n-50---20-home---0--1-00-0-0-01-1-0utfZz-8-00\&a=p\&p $=$ about $\& \mathrm{c}=$ antik

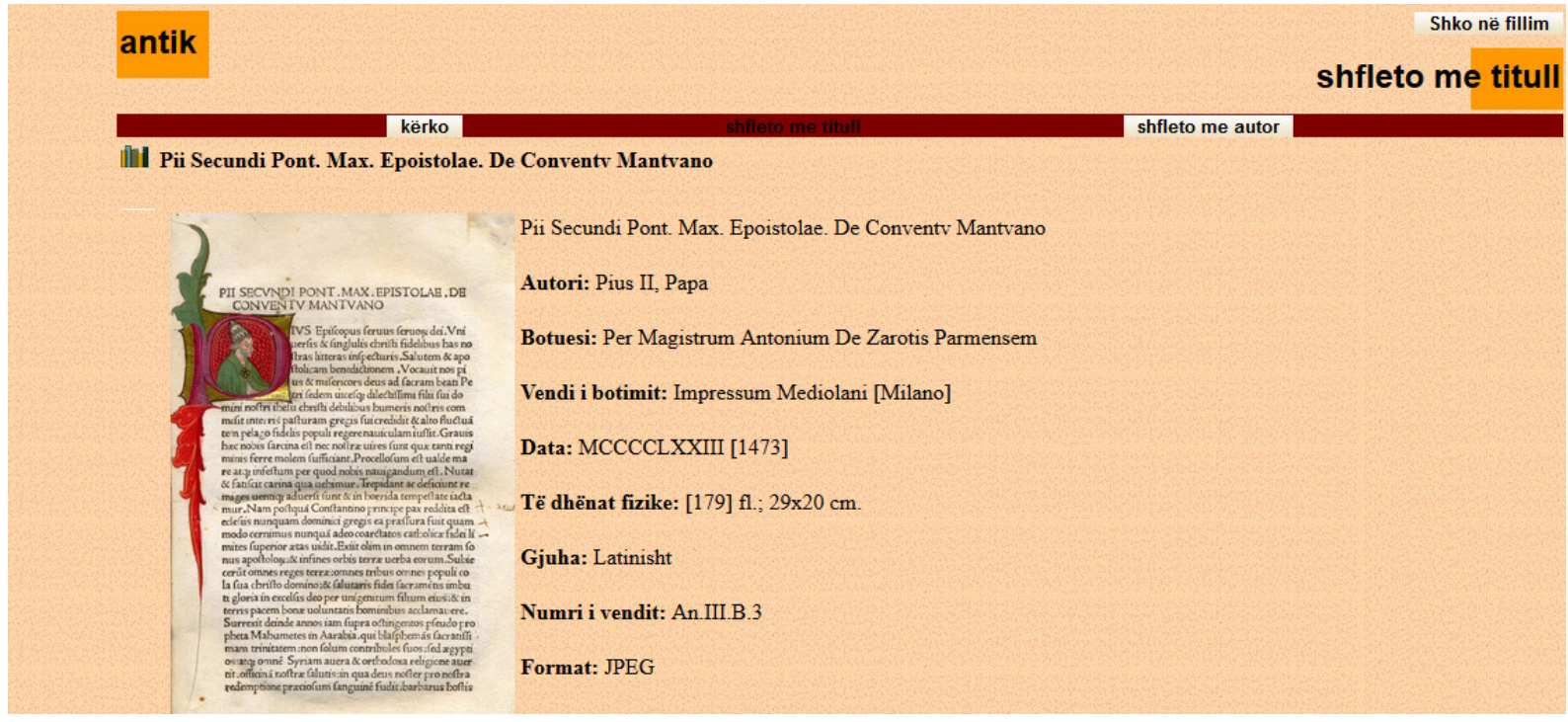

E. S. Piccolomimi: De ConventvMantvano ${ }^{I}$

Figure 3. The earliest publication in antiquary collections 
78 units are available online in the Antiquary digital maps collection including publications of European map designers from XV-XVIII centuries (Coronelli, Rosacchio, Ortelio etc.). Such kind of collection is a source for historical, ethnographic, linguistic, geological or other studies concerning Albania and other European countries.
The entire rare collection is available online: http://www.bksh.al/gsdl/cgi-bin/library.exe? $=\mathrm{d}-01000-00$ ---off-0hartat--00-1--0-10-0---0---0prompt-10---4-------0-1 1--11-en-50---20-about---00-3-1-00-0-0-11-1-0utfZz-8-00 $\& \mathrm{a}=\mathrm{d} \& \mathrm{c}=$ hartat $\& \mathrm{cl}=\mathrm{CL} 2.10$

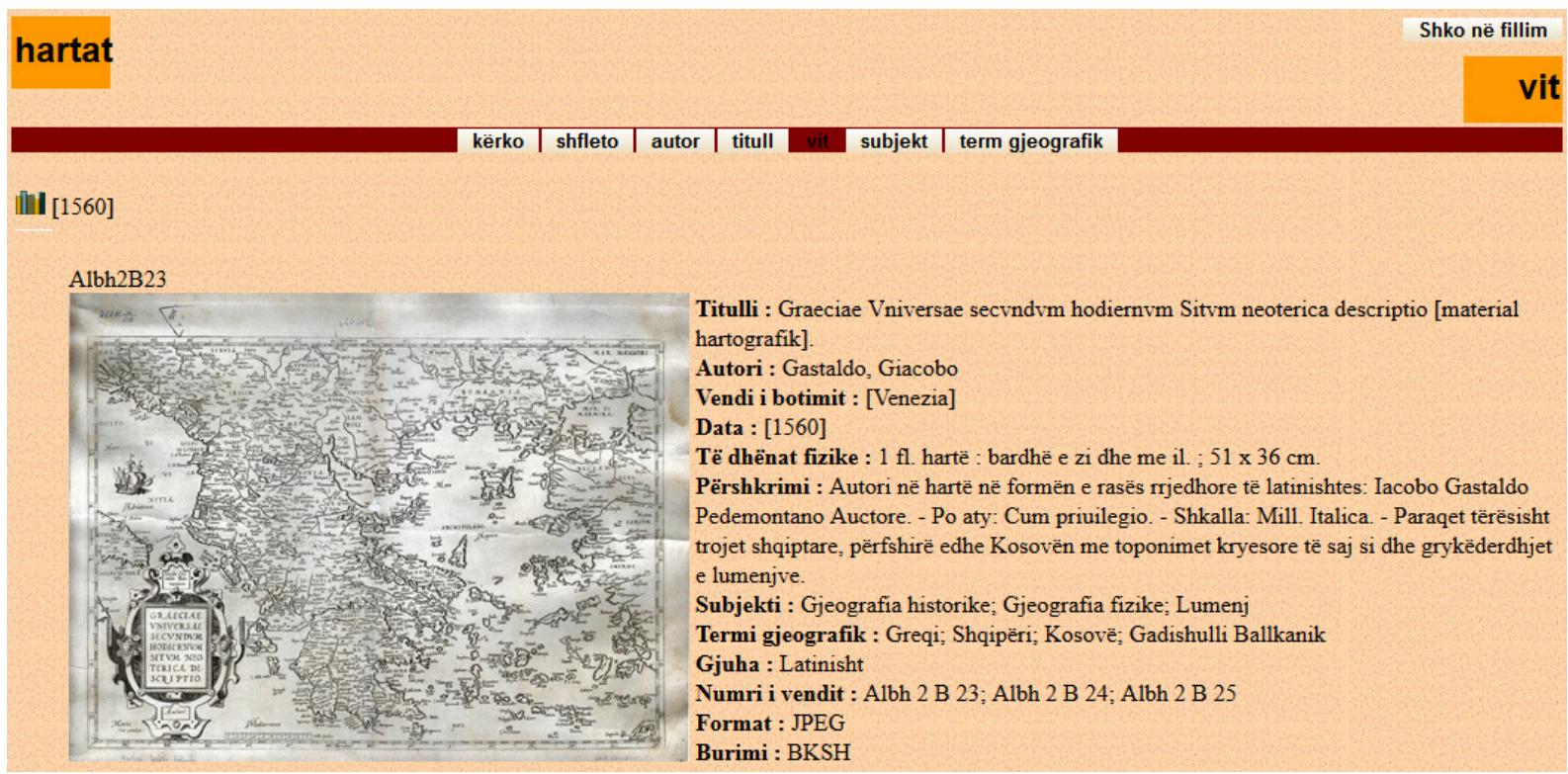

Figure 4. The earliest map in library collection ${ }^{2}$

IIII Albania Propria ouero Superiore detta anche Macedonia Occidentale [material hartografik]: descritta, con Disegni fatti sul luogo, da Giacomo Cantelli da Vignola Suddito e Geografo del Sereniss[imo] Sig[nor] duca di Modena; data in Luce dalle sue Stampe in Roma da Gio[vanni] Giac[omo] Rossi alla Pace con Priu[ilegio] Del S[ommo] P[ontificato].

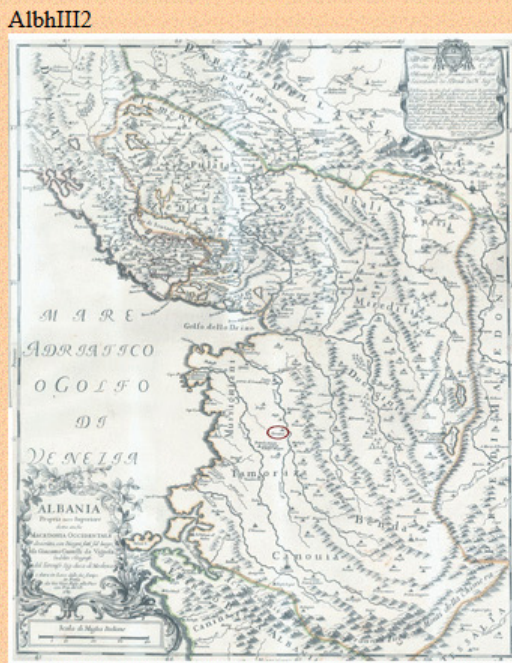

Titulli : Albania Propria ouero Superiore detta anche Macedonia Occidentale [material hartografik] descritta, con Disegni fatti sul luogo, da Giacomo Cantelli da Vignola Suddito e Geografo del Sereniss[imo] Sig[nor] duca di Modena; data in Luce dalle sue Stampe in Roma da Gio[vanni] Giac[omo] Rossi alla Pace con Priu[ilegio] Del S[ommo] P[ontificato]. Autori : Cantelli, Giacomo

Vendi i botimit : Roma

Botuesi : Gio[vanni] Giac[omo] Rossi

Data : 1689

Të dhënat fizike : $1 \mathrm{fl}$ hartë : me ngjyra ; $54,5 \times 42,8 \mathrm{~cm}$ Përshkrimi : Bashkë me hartën dhe një portret i papa Klementit XI [Gio. Franc. Albani (Clemente $\mathrm{XI})$ ], me përmasa $33 \times 24 \mathrm{~cm}$. - Scala di Miglia Italiane. - Në pjesën e pasme të hartës tekst me të dhëna në latinisht. - Kushtim i botuesit Giovani Giacomo de Rossi për papa Klementin XI (Giovanni Francesco Albani). - Për herë të parë në këtë hartë përmendet Tirana me toponiminë "Terrana" si dhe të gjitha fshatrat e saj. - Përfshihen edhe trojet e Shqipërisë së Veriut deri në Himarë. Subjekti : Gjeografia historike; Toponimia Termi gjeografik : Shqipëri

Gjuha : Italisht

Numri i vendit : Albh III 2

Format : JPEG

Burimi : BKSH

Figure 5. The capital of Albania Tirana ("Terrana") is mentioned in this map for the first time ${ }^{3}$ 
The manuscripts collection belongs to XV-XX centuries. Such collection contains gold decorated documents with illuminated ornaments, beautiful miniatures, extraordinary calligraphy where the majority is in oriental languages, such as: Arabic, Turkish or Persian language, and a small number of them is in Western and Albanian languages. The content of the said collection consists of a religious, historic, linguistic, literary and scientific nature. In this collection, treaties of savants or philosophers can be distinguished, along with different collection of poets. The manuscripts collection constitutes asset of great value for the heritage of Albanian and European culture.

In the total of 230 digitized manuscripts, a part of them is available online. http://www.bksh.al/gsdl/cgi-bin/library.exe?e=p-01000-00 ---off-0dorshkri--00-1--0-10-0---0---0prompt-10---4------0-11--11-en-50---20-about---00-3-1-00-0-0-11-1-0utfZz-8-

\section{$00 \& \mathrm{a}=\mathrm{d} \& \mathrm{cl}=\mathrm{CL} 1$}

The manuscripts in the oriental languages have a religious, historic, linguistic, literary and scientific content. The manuscripts of historical theme consist of a special interest where the "munsheatet" or documentary chrestomacies (official documents or private correspondence) handle events, describe places or deals with various personalities of Albanian history. The treaty of the famous Iranian savant Ibn Sina and well-known Greek philosopher Aristotle are distinguished among the manuscripts of scientific and philosophical content. The series of literary works are dominated by "divans" with erotic, social and religious poetry of foreign authors such as: Feridun, Kemal or the famous Persian poet Saadi. This collection also contains a certain number of Albanian manuscripts which are written in Arabic alphabet and belong to XVIII-XIX century.

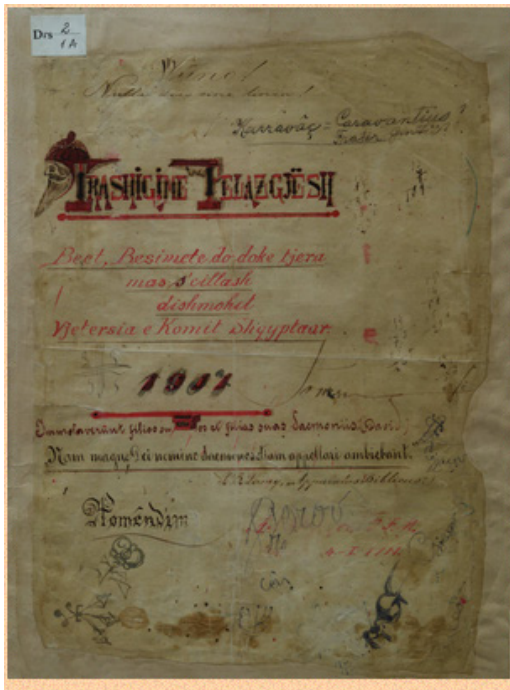

Titulli: Trashigime Pelazgjësh : Beet, Besimete do doke tjera mas s'cillash dishmohet vjetersi e Komit Shqyptaar

Autori: Gjeçovi, Shtjefën K.

Vendi i botimit: Gomsiqe

Data: 1908

Të dhënat fizike: $60 \mathrm{fl}$; $39 \mathrm{~cm}$

Gjuha: Shqip

Numri i vendit: Drs.2.A.1

\begin{tabular}{l}
\hline$\rightarrow$ C \\
S: Go back one page \\
Save Page to Pocket \\
View Background Image \\
Select All \\
View Page Source \\
View Page Info \\
Inspect Element $(Q)$ \\
\hline
\end{tabular}

Përshkrimi: Vendi dhe viti i dorëshkrimit janë marrë nga parathënia. Me argumente historike etnologjike dhe fetare autori vërteton lashtësinë e kombit shqiptar. Gjeçovi merret me tezën e prejardhjes së shqiptarëve. Ai nënvizon faktin se shqiptarët janë popull më i vjetër se grekët e latinët dhe doket e zakonet $i$ kanë të trashëguara nga të parët e tyre pellazgë.

Figure 6. Albanian manuscripts ${ }^{4}$ 


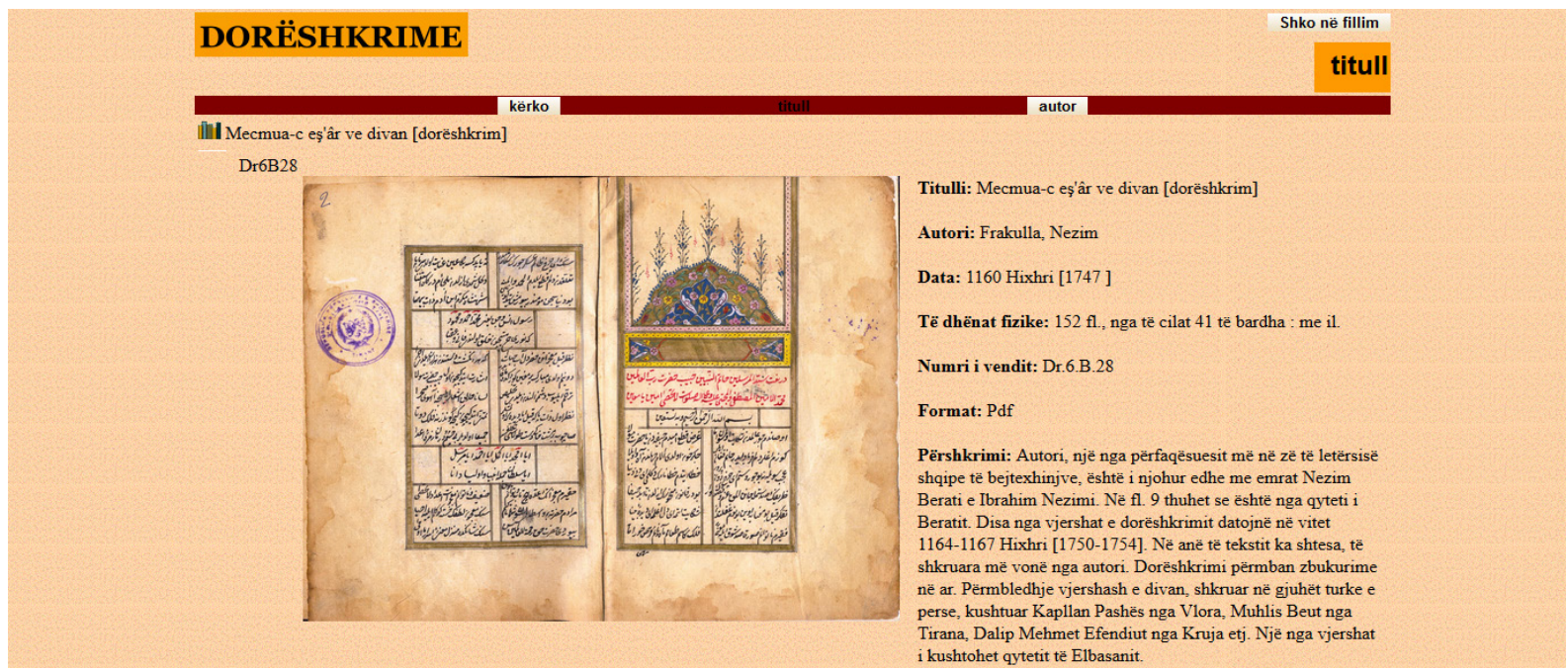

Figure 7. Oriental manuscripts ${ }^{5}$

The Collection of Albanian Archives comprises books and periodicals beginning from the first publications in the Albanian language (XVI century) till nowadays which are printed in Albanian language and published in Albania or abroad. Such collection of archives is mainly enriched by the legal deposit law including: works of outstanding personalities of the Albanian culture; a considerable number of unique works by authors of the Albanian National Renaissance, as well as the first issues of Albanian periodicals; publications of Albanian scholars and authors in all areas of knowledge; Albanian artistic literature and translations in Albanian language from the world literature. Currently, 100 books and 100 cultural magazines from the time period 1883-1944 are provided in a digital format.

A part of the above-mentioned digitized books and magazines are also available online: http://www.bksh.al/gsdl/cgi-bin/library.exe?e=p-00000-00---off-0--00---0-10-0---0---0prompt-10---4-------0-11--10-en-5 0---20-home---0--1-00-0-0-01-1-0utfZz-8-00\&a=p\&p=about\&c=revistaa

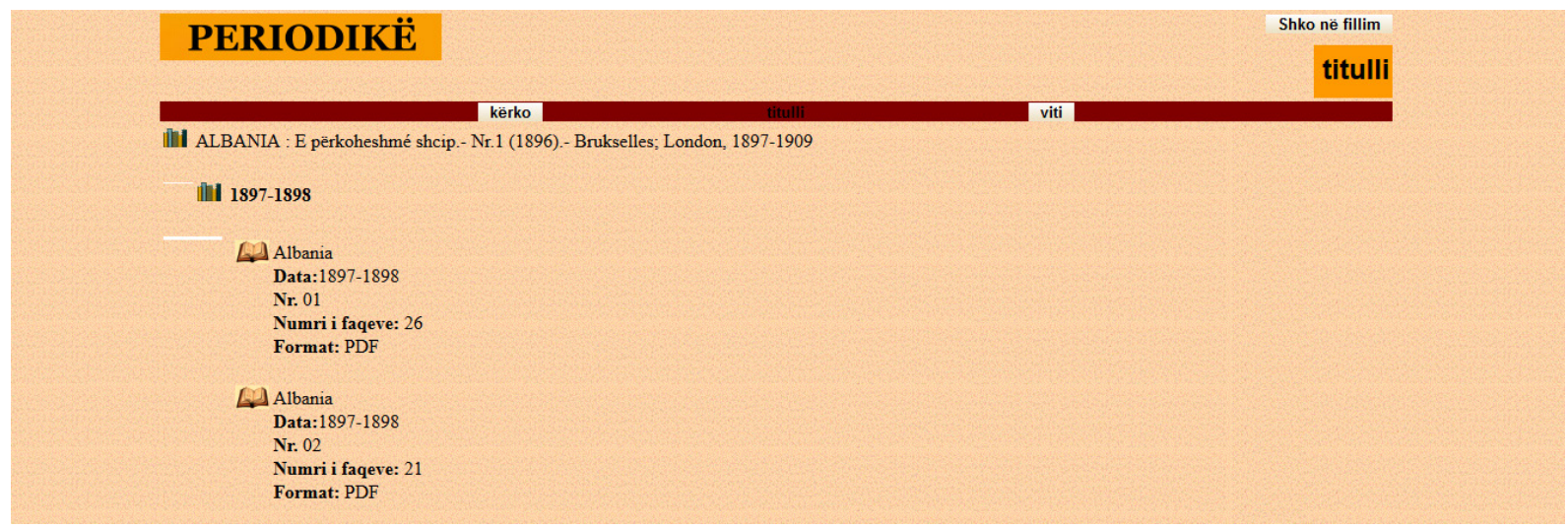

Figure 8. One of the most important Albanian cultural periodical ${ }^{6}$

Albanian and foreign publications handling with Albania, Albanians and other Balkan peoples, as well as in relation to their history, language, folklore, anthropology, geography, culture etc. are conserved in the Albano-Balkanological collection.

Among the works of Albanian scholars, studies on Albanian language or Albanian people, as well as studies on their customs, traditions etc., a good number of works of well-known scholars, such as: Pouqueville, Xylander, Hahn, Bopp, Meyer, Jokle, Sufflay, Thaloczy, Babinger, Iorga etc. are also preserved. This collection includes editions from 1800 until nowadays and serves as a basic literature for albanlogical studies. Currently, the center of Albanological studies is concentrated in Albania and the basic literature for these studies is found in NLA.

5http://www.bksh.al/gsdl/c gi-bin/library.exe?e=d-01000-00---off-0dorshkri--00-1--0-10-0---0---0prompt-10---4-------0-11--11-en-50---20-about---00-3

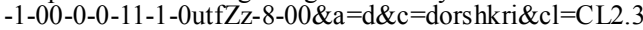

6 www.bksh.al/gsdl/cgi-bin/library.exe?e=d-01000-00---off-0revistaa--00-1--0-10-0---0---0prompt-10---4-------0-11--11-en-50---20-about---00-3-1-00$0-0-11-1-0$ utfZz-8-00\& $\mathrm{a}=\mathrm{d} \& \mathrm{c}=$ revistaa\&cl $=$ CL1.2.1 
These treasures consist of European cultural heritage's representations through the centuries and play an important role in human sciences enabling the NLA to be ranked besides its homologues libraries in the new digital era with a special project.

\subsubsection{International Level}

NLA has been included in different European projects. Due to the involvement in FUMAGABA project, NLA became a full member of The European Library (TEL) and had opportunities to make searchable its collections via TEL portal. FUMAGABA was the first opportunity for National Library of Albania to widely promote the Albanian cultural heritage in the European portal, that is, a portal which actually also "speaks" in Albanian language.

The NLA's digital objects, - distributed even via EUROPEANA (a multi-lingual online collection of millions of digitized items from European libraries, archives, museums and audiovisual collections), - are easily searchable through the world website for all the clients/users.

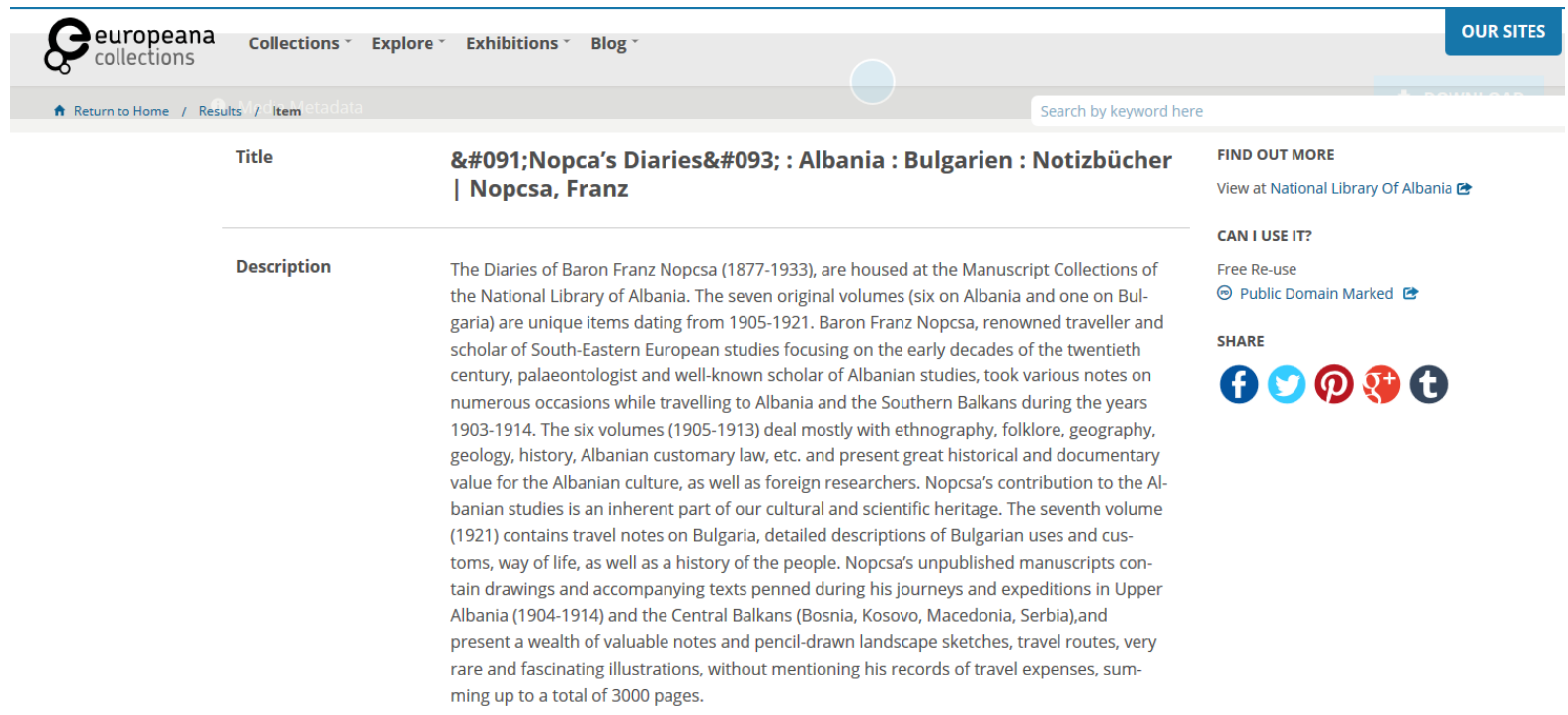

Diaries of Baron Franz Nopcsa (renowned traveler and scholar of South-Eastern European studies) ${ }^{7}$

Figure 9. Unique original manuscripts items (unpublished).

In 2009, a partnership invitation came from UNESCO and Library of Congress with the aim to include the Albanian digital cultural heritage in the World Digital Library by giving us the opportunity to be listed as a partner in the world digital portal. 

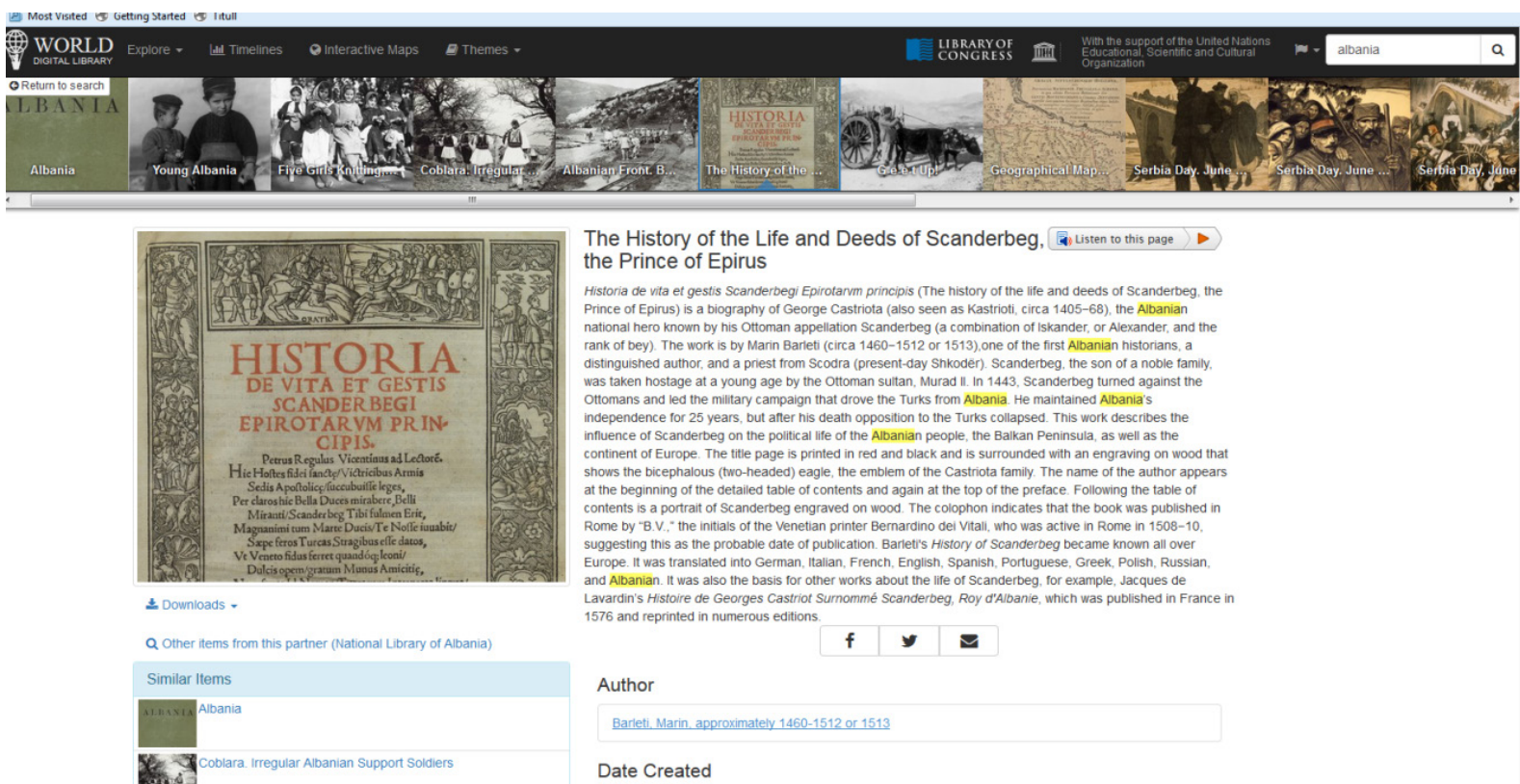

Similar Items

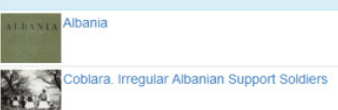

Date Created

[Barletius, Marinus]: Historia de vita et gestis Scanderbegi Epirotarum principis ${ }^{8}$

Figure 10. One of the most important concerning the historical-documentary value of Albanian culture

Table 2. NLA website comparison: December 31, 2009 - December 31, 2016

\begin{tabular}{|c|c|c|c|c|c|c|c|c|}
\hline Number of & $\begin{array}{c}\text { December } \\
\mathbf{2 0 0 9}\end{array}$ & $\begin{array}{c}\text { December } \\
\mathbf{2 0 1 0}\end{array}$ & $\begin{array}{c}\text { December } \\
\mathbf{2 0 1 1}\end{array}$ & $\begin{array}{c}\text { December } \\
\mathbf{2 0 1 2}\end{array}$ & $\begin{array}{c}\text { December } \\
\mathbf{2 0 1 3}\end{array}$ & $\begin{array}{c}\text { December } \\
\mathbf{2 0 1 4}\end{array}$ & $\begin{array}{c}\text { December } \\
\mathbf{2 0 1 5}\end{array}$ & $\begin{array}{c}\text { December } \\
\mathbf{2 0 1 6}\end{array}$ \\
\hline $\begin{array}{c}\text { Visitors (new \& } \\
\text { returning) }\end{array}$ & 14,773 & 15,304 & 43,786 & 43,850 & 51,023 & 60,855 & 77,517 & 90,397 \\
\hline Visits to site & 25,048 & 26,558 & 68,087 & 69,273 & 85,042 & 200,811 & 219,547 & 234,366 \\
\hline $\begin{array}{c}\text { Countries represented } \\
\text { by users }\end{array}$ & 103 & 111 & 101 & 119 & 122 & 125 & 131 & 127 \\
\hline $\begin{array}{c}\text { Languages represented } \\
\text { by users }\end{array}$ & 61 & 69 & 96 & 110 & 121 & 146 & 158 & 143 \\
\hline $\begin{array}{c}\text { Users who accessed } \\
\text { subpages }\end{array}$ & 69,422 & 81,274 & 182,984 & 200,517 & 250,588 & 305,517 & 324,861 & 358,413 \\
\hline Searches in the OPAC & 38,138 & 40,279 & 89,086 & 89,100 & 109,417 & 200,811 & 219,547 & 169,558 \\
\hline $\begin{array}{c}\text { Visits to digitized } \\
\text { catalogs }\end{array}$ & 1,875 & 611 & 4,490 & 6,108 & 6,247 & 6,019 & 6,046 & 6,880 \\
\hline $\begin{array}{c}\text { Digital Albanological } \\
\text { Library }\end{array}$ & - & 794 & 1,399 & 2,623 & 1,753 & 2,119 & 3,785 & 7,797 \\
\hline
\end{tabular}




\subsection{Statistical NLA's Website Data}

NLA continuously looks for new ideas and changes. Among the last years, a lot of things have been made in our institution. The best librarians and IT specialists were involved in the work and development of digital strategy with the conviction that such a huge transformation would affect the relation between clients/users and library collections even out the "National Library Walls". It is a huge achievement for us to offer facilities to access the digital collections.

The virtual "book-reader" relation helped in increasing the number of persons who navigated in the National Library of Albania website.

According the website statistics, the number of website users has increased from year to year in relation to the following sections: Albanian Digital Library, e-Bibliography, digitized catalogues. My research monitoring the National Library of Albania website from January 1, 2009 to December 31, 2016 shows that the statistical indicators are satisfactory.

\section{Conclusions}

In this briefly overview of Albanian Digital Library "village", it is clear/evident that "Albanian Cultural Heritage by a click of mouse" is a "new channel" in the universe of knowledge by breaking the concept of "physical boundaries", "building bridges" and "connecting cultures across the world". Initiatives on a large-scale such as EUROPEANA and World Digital Library that promote Albania to global online community, serve as excellent "green lights" in the portals of knowledge by making
European and/or World cultural and scientific heritage accessible to all on the internet.

By believing in the good will of librarians for bringing together the "memory" of past and present, the vision of library future is positive. The objective of National Library of Albania to create the digital "village" is only a very small drop in the ocean of knowledge. However, we are fully optimist that better and faster services will come for clients/users who require more and more new information gateways.

\section{REFERENCES}

[1] Heraclitus. Retrieved September 15, 2017, from http://thinkexist.com/quotation/there_is_nothing_permanen t_except_change/13662.html

[2] Ranganathan, S. R. Five Laws of Librarianship, Bangalore, 2006. Retrieved September 15, 2017, from http://en.wikipedia.org/wiki/Five_laws_of_library_science

[3] IFLA/UNESCO Manifesto for Digital Libraries, 2010. Retrieved September 15, 2017, from http://www.ifla.org/publications/iflaunesco-manifesto-for-d igital-libraries

[4] Bogova, I. (2013). UNESCO's General Director Introduction Message for "World Book Day and Copyright Day 2013". Retrieved December 19, 2014, from http://www.unesco.org/new/en/events/bookday/2013/dsmes sage.html

[5] IFLA/UNESCO Manifesto for Digital Libraries, 2010. Retrieved September 15, 2017, from $\mathrm{http}: / /$ www.ifla.org/publications/iflaunesco-manifesto-for-d igital-libraries 